\title{
EFFECTS OF POLYCHLORINATED BIPHENYLS ON HUMORAL IMMUNITY AND BLOOD SERUM VITAMIN A AND E CONCENTRATION OF CHICKS
}

\author{
R. HALOUZKA ${ }^{1}$, V. JURAJDA ${ }^{2}$ and E. MINKSOVÁ \\ Department of Pathomorphology ${ }^{1}$, Clinic of Avian Diseases ${ }^{2}$, Clinic of Internal Medicine ${ }^{3}$, \\ University of Veterinary and Pharmaceutical Sciences, 61242 Brno
}

Received February 26, 1993

\begin{abstract}
Halouzka R., V. Jurajda and E. Minksová: Effects of Polychlorinated Biphenyls on Humoral Immunity and Blood Serum Vitamin A and E Concentration of Chicks. Acta vet. Brno, 63, 1994: 141-144.

The effects of ingestion of a feed contaminated with polychlorinated biphenyls (PCB) using Delor 103, a technical preparation, on the dynamics of haemagglutination-inhibiting (HI) antibodies to Newcastle disease virus (NDV) after administration of Czechoslovak vaccine Avipest (LaSota) were studied in an in-vivo experiment. Blood serum vitamin $A$ and $E$ concentrations were assessed at the end of the experiment.

Brown Hisex layer-type hibrid cockerels from a commercial flock were fed a feed mixture supplemented with Delor 103 at the rate of $25 \mathrm{mg} \cdot \mathrm{kg}^{-1}$ or $50 \mathrm{mg} \cdot \mathrm{kg}^{-1}$ feed from 1 day of age till the end of the experiment in the 10th week. In the 3rd post-hatching week they received vaccine against NDV in drinking water. The level of post-vaccination immunity was checked at 14-day intervals. Vitamin concentrations were assessed with fluorescence spectrophotometry. Compared with the control birds, the two PCB-fed groups showed a lower HI antibody level in the 4th, 6th and 10th week. No differences in the reduction of immunity due to the different PCB levels in the feed were recorded. Vitamin A concentration was significantly $(P \leq 0.05)$ lower in both experimental groups than in the controls. Vitamin E concentration of the group fed the feed mixture contaminated with Delor 103 at $25 \mathrm{mg} \cdot \mathrm{kg}^{-1}$ was significantly $(P \leq 0.05)$ higher than in the controls.

Continued feeding of a PCB-contaminated feed mixture to chickens may be involved in delayed development, fluctuation or reduction of their post-vaccination humoral immunity against NDV.
\end{abstract}

Brown Hisex chickens, PCB, post-vaccination immunity, NDV.

Atrophy of lymphoid tissues observed in various animal species after ingestion of feeds containing polychlorinated biphenyls (PCB) has been regarded as a morphological correlate of their immunosuppressive effects (Cos 1972; Vos and De Roij 1972; Vos and van Driel-Grootenhuis 1972; Halouzka and Jurajda 1991). However, published direct evidence for depressed immune response in poultry has been scarce.

In a previous report (H a lo u z a et al. 1990) we demonstrated morphological changes in the lymphoid organs of chickens fed a PCB-contaminated feed. The present report was designed to study the effects of PCB on the development and dynamics of humoral antibodies after vaccination against Newcastle disease and on blood serum vitamin $A$ and $E$ concentration.

\section{Materials and Methods}

The experimental birds were 1-day old Brown Hisex layer-type hybrid cockerels from a commercial flock. They were divided at random into 3 groups and fed a commercial feed mixture ad libitum. The feed mixture was contaminated with PCB in the form of Delor 103, a technical preparation, at the rate of $25 \mathrm{mg} \cdot \mathrm{kg}^{-1}$ (Group 1) or $50 \mathrm{mg} \cdot \mathrm{kg}^{-1}$ feed (Group 2). Checks on the PCB content of the feed mixture before and after its contamination were made with gas chromatography (Vá v rová 1984). Group 3 birds were fed the non-contaminated feed mixture and served as controls.

At 3 weeks of age all cockerels were vaccinated against Newcastle disease (ND) with Avipest (strain LaSota), a Czechoslovak vaccine, administered in drinking water.

Groups of 10 cockerels of each group were weighed and sacrificed by decapitation at 14-day intervals. The blood sera were examined with the haemagglutination-inhibition (HI) test for the presence of humoral antibody. The HI test was carried out according to Beard (1980) in U-type microtitration plates using method beta, i. e. serial dilution of the sera in PBS containing 8 haemagglutination units of the virus (LaSota) in 50 ul volumes; the initial serum dilution was 1:5. The $\mathrm{HI}$ antibody titre in the dilution of 1:20 or higher was regarded as positive.

At the end of the experiment (10th week) blood serum vitamin $A$ and $E$ concentrations were determined using fluorescent spectrophotometry according to Thomps on et al. $(1971,1973)$.

The results were evaluated using Student's t-test and chi-squared test according to Fisher (Re is e n a u er 1965). 


\section{Results}

Data concerning the health status of the birds, pathomorphological findings and PCB residues in the muscles were reported previously (Ha lo u z ka et al. 1993). Before contamination, PCB concentration of the feed was below the detectability level. After contamination it ranged between 0.056 and $1.458 \mathrm{mg} . \mathrm{kg}^{-1}$ in Group 1 and between 1.831 and $3.574 \mathrm{mg} . \mathrm{kg}^{-1}$ dry feed in Group 2.

The results of serological examination are presented in Table 1 and the blood serum vita$\min \mathrm{A}$ and $\mathrm{E}$ concentrations in the 10th post-hatching week are shown in Table 2.

The level of the post-vaccination humoral immunity against NDV in cockerels fed the PCB-contaminated feed was reduced in 4th, 6th and 10th week of age, different serum positivity being recorded only in the 4th post-hatching week. The serum positivity recorded in the 2 nd post-hatching week corresponded to passively acquired immunity.

Table 1

HI antibody titres to NDV in the sera of Hisex Brown chickens fed a PCB-containing feed mixture for 10 weeks 1

\begin{tabular}{|c|c|c|c|c|}
\hline $\begin{array}{c}\text { Age } \\
\text { (weeks) }\end{array}$ & $\begin{array}{l}\text { Group of } \\
\text { chickens }\end{array}$ & $\begin{array}{l}\text { Delor } 103 \\
\mathrm{mg} \cdot \mathrm{kg}^{-1}\end{array}$ & $\begin{array}{c}\text { Serum } \\
\text { positivity }\end{array}$ & $\mathrm{GMT}^{3}$ \\
\hline 2 & $\begin{array}{l}1 \\
2 \\
3 \\
\end{array}$ & $\begin{array}{r}25 \\
50 \\
- \\
-\end{array}$ & $\begin{array}{r}8 / 10 \\
8 / 10 \\
8 / 10 \\
\end{array}$ & $\begin{array}{r}21 \\
30 \\
28 \\
\end{array}$ \\
\hline 4 & $\begin{array}{l}1 \\
2 \\
3\end{array}$ & $\begin{array}{l}25 \\
50 \\
-\end{array}$ & $\begin{array}{l}2 / 10 \\
4 / 10 \\
10 / 10\end{array}$ & $\begin{array}{l}12^{\mathrm{a}} \\
12^{\mathrm{a}} \\
61\end{array}$ \\
\hline 6 & $\begin{array}{l}1 \\
2 \\
3\end{array}$ & $\begin{array}{l}25 \\
50 \\
-\end{array}$ & $\begin{array}{l}-5 / 10 \\
8 / 10 \\
10 / 10\end{array}$ & $\begin{array}{l}17^{\mathrm{a}} \\
37^{\mathrm{a}} \\
197\end{array}$ \\
\hline 8 & $\begin{array}{l}1 \\
2 \\
3\end{array}$ & $\begin{array}{l}25 \\
50\end{array}$ & $\begin{array}{l}8 / 10 \\
10 / 10 \\
10 / 10\end{array}$ & $\begin{array}{c}57 \\
75 \\
130\end{array}$ \\
\hline 10 & $\begin{array}{l}1 \\
2 \\
3\end{array}$ & $\begin{array}{l}25 \\
50 \\
-\end{array}$ & $\begin{array}{c}7 / 10 \\
7 / 10 \\
1 / 10\end{array}$ & $\begin{array}{l}26^{\mathrm{a}} \\
23^{\mathrm{a}} \\
75\end{array}$ \\
\hline
\end{tabular}

' Chickens vaccinated with Czechoslovak vaccine Avipest in the 3rd post-hatching week.

${ }^{2}$ No. positive/No. examined.

${ }^{3}$ Reciprocal value of the geometric mean titre (GMT) of HI antibodies. Values designated with letter a were significantly $(\mathrm{p}<0.05)$ different from those of the control group.

Table 2

Vitamin A and $\mathrm{E}$ concentratios ( $\mathrm{umo} / \mathrm{h})$ in the blood sera of Brown Hisex chickens in the 10th post-hatching week

\begin{tabular}{|c|c|c|c|}
\hline $\begin{array}{c}\text { Group of } \\
\text { chickens }\end{array}$ & $\begin{array}{c}\text { Delor } 103 \\
\mathrm{mg} \cdot \mathrm{kg}^{-1}\end{array}$ & $\begin{array}{c}\text { Vitamin } \mathrm{A} \\
\mathrm{x} \pm \mathrm{SD}^{1}\end{array}$ & $\begin{array}{c}\text { Vitamin } \mathrm{E} \\
\mathrm{x} \pm \mathrm{SD}^{1}\end{array}$ \\
\hline 1 & 25 & $4.143 \pm 0.540^{\mathrm{b}}$ & $\begin{array}{c}33.373 \pm 8.241^{\mathrm{b}} \\
27.876 \pm 7.642^{\mathrm{b}} \\
2\end{array}$ \\
3 & 50 & $3.488 \pm 0.863^{\mathrm{b}}$ & $26.937 \pm 4.493^{\mathrm{a}}$ \\
\hline
\end{tabular}

${ }^{\prime} \mathrm{x} \pm \mathrm{SD}=$ arithmetic mean \pm standard deviation. Values designated with different letters were significantly $(\mathrm{p}<0.05)$ different. Vitamin A concentration was lower in both experimental groups than in the control group. Vitamin $E$ concentration, on the other hand, was higher in Group 1 fed the feed mixture contaminated with the lower dose of Delor 103.

\section{Discussion}

PCB were reported to be the cause of increased susceptibility of ducklings to infectious hepatitis virus by Friend and Trainer (1970). In our previous study (Halou zka and J u r aj d a ) on the effects of PCB on the infection of chickens with turkey herpes virus (HVT) we found a reduction in HVT-antibody titre. 
From the present results it appears that a PCB-contaminated feed also reduces the level of post-vaccination haemagglutination-inhibiting antibody to NDV. The lower serum positivity observed only in the 4th week of age (i. e. 7 days after vaccination) in the groups of cockerels fed the contaminated feed mixture indicates a slower $\mathrm{HI}$ antibody production that remained below the level found in the control group throughout the observation period.

The significant decrease in vitamin $\mathrm{A}$ level is in keeping with the results reported by Cecil et al. (1973). It correlated with the PCB dose and was presumably involved in the development of skin and gonad lesions and also in sporadically observed epithelial metaplasia. The increase in vitamin $E$ level is at variance with the observations of Co $\mathrm{mbs}$ et al. (1975) who found that experimental PCB-fed chickens showed a tendency to selenium and vitamin E deficiency. The present findings are apparently the consequence of a complex PCB-induced metabolic disorder.

From the results reported here it can be concluded that polychlorinated biphenyls may be involved in the reduction of antibody response after vaccination against NDV.

\section{Vliv polychlorovaných bifenylů na humorální imunitu po vakcinaci proti Newcastleské nemoci a na koncentraci vitamínủ A a E v krevním séru kư̌at}

V pokusu in vivo jsme sledovali vliv př́jmu krmiva kontaminovaného chlorovanými bifenyly (PCB) ve formě technického př́pravku Delor 103 na dynamiku tvorby hemaglutinačně inhibičních (HI) protilátek proti viru Newcastleské nemoci (NDV) po aplikaci čs. vakcíny Avipest (LaSota). Při ukončení pokusu jsme stanovili koncentrace vitamínủ A a E v krevních sérech kư̌at.

Kohoutci nosného hybrida Hisex hnědý z komerčního chovu byli krmeni od 1. dne věku do konce pokusu (10 týdnů) krmnou směsí s př́davkem Deloru $103 \mathrm{v}$ dávkách $25 \mathrm{mg} . \mathrm{kg}^{-1}$ nebo $50 \mathrm{mg} \cdot \mathrm{kg}^{-1}$. Vakcína proti NDV byla aplikována v pitné vodě v 3. týdnu věku kohoutkủ. Hladina postvakcinační imunity byla sledována ve 14denních intervalech. Koncentrace vitamínů byla stanovována fluorescenční spektrofotometrií. Ve 4., 6. a 10. týdnu věku byla zjištěna nižší hladina HI protilátek u obou skupin kohoutkủ krmených PCB kontaminovanou krmnou směsí v porovnání $s$ kontrolní skupinou. Rozdíly v redukci imunity vlivem odlišné dávky PCB v krmivu nebyly pozorovány. Koncentrace vitamínu A byla signifikantně nižši $(\mathrm{p}<0,05)$ u obou pokusných skupin v porovnání s kontrolní skupinou. Koncentrace vitamínu E byla signifikantně vyšsí $(\mathrm{p}<0,05)$ u skupiny krmené směsí kontaminovanou Delorem $103 \mathrm{v}$ dávce $25 \mathrm{mg} \cdot \mathrm{kg}^{-1} \mathrm{v}$ porovnání s kontrolou.

Déletrvající kontaminace krmné směsi PCB se může podílet u kư̌at na opožděném vzniku či kolísání anebo redukci hladiny humorální postvakcinační imunity proti NDV.

\section{Влияние полихлорированных дифөнилов на гуморальный иммунитөт и на концөнтрацию витаминов А и Е в кровяной сывороткө цыплят}

В ходе експеримента ин виво проводили наблюдения приема пищи, контаминированной хлорированными дифенилами (РСВ) в форме технического препарата Делоп 103, определяя влияние на динамику образования гемаглютинационно-ингибирующих (HI) антител против вируса ньюкастлеской болезни (NDV) после применения чехословацкой вакцины Авипест (ЛаСота). При завершении эксперимента определяли концентрацию витаминов А иЕ в сыворотке крови цыплят.

Петушков несущего гибрида Гисекс коричневый коммерческого птицеводства кормили с 1 суток до конца эксперимента (10 суток) кормовой смесью с добавлением Делора 103 дозой

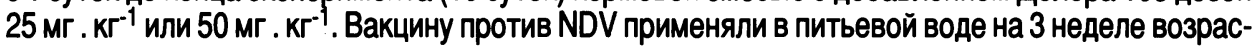


та петушков. Уровень послевакцинационного иммунитета исследдовали в двухнедельных интервалах. Концентрацию витаминов определяли флуоресцентной спектрофотометрией. На 4, 6 и 10 неделе возраста установили более низкий уровенъ НІ антител обеих групп петушков, кормленных РСВ контаминированной кормовой смесью по сравнению с контрольной группой. Разницу редукции иммунитета в результате разной дозы РСВ в корме не наблюдали. Концентрация витамина Абыла у обейх подопытных групп по сравнению сконтрольной группой ниже. Концентрация витамина Е была больше у группы, питаемой смесью, контаминированной Делором 103 дозой 25 мг . кг-1 по сравнению с контрольной группой.

Длительная контаминация кормовой смесью РСВ может у цыплят оказать влияние на запоздалое возникновение или колебание, а также редукцию уровня гуморального послевакцинационного иммунитета против NDV.

\section{References}

BEARD, C. W.: Serologic procedures. In: Isolation and identification of avian pathogens (eds. S. B.Hitchner et al.), 2nd Ed. AAAP, Univ. Coll. Texas, 1980: 129-135

CECIL, H. C. - HARRIS, S. J. - BITMAN, J. et al.: Polychlorinated biphenyl-induced decrease in liver vitamin A in Japanese quails and rats. Bull. Environ. Contam. Toxicol., 9, 1973: 179-185

COMBS, G. F. jr. - CANTOR, A. H. - SCOTT, M. L.: Effects of dietary polychlorinated biphenyls on vitamin E and selenium nutrition in the chick. Poult. Sci., 54, 1975: 1143-1152

FRIEND, M. - TRAINER, D. O.: Polychlorinated biphenyls: interaction with duck hepatitis virus. Science, 170, 1970: 1314-1316

HALOUZKA, R. - JURAJDA, V.: Morphological expression of immunosuppression in poultry. Acta vet. Bmo, 60, 1991: 271-276

HALOUZKA, R. - JURAJDA, V.: Patologické změny orgánù kư̌at po infekci krùtím herpetickým virem THV-BIO-I. Veter. Med. (Praha), 37, 1992: 463-470

HALOUZKA, R. - RUPRICH, J. - PISKAČ, A.: Úđinek polychlorovaných bifenylú (PCB) na organismus kưaat: patologické změny orgánủ po krátkodobém a dlouhodobém př́ijmu vysokých dávek Deloru 103 . Veter. Med. (Praha), 35, 1990: 303-312

HALOUZKA, R. - JURAJDA, V. - VÁVROVÁ, M.: Experimental chronic intoxication of chickens with polychlorinated biphenyls (Delor 103). Acta vet. Brno, 62, 1993: 151-157

REISENAUER, R.: Metody matematické statistiky a jejich aplikace. Praha, SNTL 1965, $210 \mathrm{p}$

THOMPSON, J. N. - ERDODY, P. - BRIÉN, R. et al.: Fluorometric determination of vitamin A in human blood and liver. Biochem. Med. 5, 1971: 67-89

THOMPSON, J. N. - ERDODY, P. - MAXWELL, W. B.: Simultaneous fluorometric determination of vitamin $A$ and $E$ in human serum and plasma. Biochem. Med., 8, 1973: 403-414

VÁVROVÁ, M.: Stanovení reziduí polychlorovaných bifenylú v biologickém materiálu chromatografickými metodami. Ph.D. Thesis, VŠV Brno, 1984, 138 p.

VOS, J. G.: Toxicology of PCBs for mammals and for birds. Environ. Health Perspect., 1, 1972: 105-117

VOS, J. G. - De ROIJ, T. H.: Immunosuppressive activity of a polychlorinated biphenyls preparations on the humoral immune response in guinea pigs. Toxicol, Appl. Pharmacol, 21, 1972: 549-555.

VOS, J. G. - DRIEL-GROOTENHUIS, van L.: PCB - induced suppression of the humoral and cell-mediated immunity in guinea pigs. Sci. Total Environ, 1, 1972: 289-302. 